\title{
Urgences
}

\section{Question de ça}

\section{Georges Dessagne}

Numéro 20, mai 1988

Appellation contrôlée

URI : https://id.erudit.org/iderudit/025465ar

DOI : https://doi.org/10.7202/025465ar

Aller au sommaire du numéro

Éditeur(s)

Urgences

ISSN

0226-9554 (imprimé)

1927-3924 (numérique)

Découvrir la revue

Citer ce document

Dessagne, G. (1988). Question de ça. Urgences, (20), 15-16.

https://doi.org/10.7202/025465ar

Ce document est protégé par la loi sur le droit d'auteur. L'utilisation des services d'Érudit (y compris la reproduction) est assujettie à sa politique d'utilisation que vous pouvez consulter en ligne.

https://apropos.erudit.org/fr/usagers/politique-dutilisation/
Cet article est diffusé et préservé par Érudit.

Érudit est un consortium interuniversitaire sans but lucratif composé de l’Université de Montréal, l'Université Laval et l'Université du Québec à Montréal. Il a pour mission la promotion et la valorisation de la recherche. https://www.erudit.org/fr/ 


\section{GEORGES DESSAGNE Question de ça}

Je n'ai pas d'histoire. Les histoires, d'ailleurs, il y a longtemps que je n'y crois plus. Les enfants, peut-être, en ont encore qui traînent dans leurs tiroirs. Des enfants, je n'en ai pas, je n'en ai pas voulu. Et je suis têtu. Et puis, les adultes - c'est bien connu - n'aiment pas ça, les histoires, à moins qu'elles soient comme ils les veulent, pas autrement. C'est bien pourquoi, moi, des histoires, je n'en raconte pas.

Ma vie n'est pas une histoire. Des fois je me dis qu'elle ressemble à un drap: pas celui sur lequel un homme a dormi, mais celui qu'une femme a repassé, puis qu'elle aura replié et oublié dans le fond d'une armoire. Ma vie, c'est ça. Et mes voisins ont beau avoir les yeux plissés, le visage ridé, je n'en demeure pas moins convaincu que, d'histoire, ils n'en ont pas plus que moi.

Quand je me promène dans les rues, c'est du pareil au même, toujours. Des gens si plats que le moindre coup de vent pourrait les emporter. Ça se comprend: ils n'ont pas de poids, pas la moindre épaisseur. Rien que des surfaces qui font semblant de se promener pour s'occuper et qui n'occupent tout au plus que des jambes, parfois des bras. Il suffit de les regarder droit dans les yeux pour s'en convaincre; dedans, on ne trouve rien. Que des miroirs qui passent, sans tain.

Voilà pourquoi, moi, j'ai choisi de ne plus leur accorder la moindre importance. Comme s'ils n'existaient pas, comme si plus personne, pour moi, n'avait d'existerice. J'ai fait le vide et depuis, ma foi, je ne m'en porte que mieux, plus plein en dedans d'un vide irremplissable (irremplaçable?), avec la conscience aiguë pour le moins d'exister - hors des autres, bien entendu, pour moi seul, mais c'est toujours ça de pris. Quand on est réduit à ça, quand on pourrait glisser entre «moi» et «ça» le signe d'équivalence, aucune arithmétique ne tient plus. Même si "ça» contient tout le reste et bien plus, même si "ça» comprend plus que "moi» et plutôt que du vide pourrait être le signe, par l'absurde, d'un trop-plein qu'on n'arrive jamais à nommer ni à cerner. En tout cas, moi, j'y crois.

Depuis que j'ai pris cette décision et que je m'applique à m'y conformer religieusement, c'est fou ce que j'étonne les gens, ce qu'ils me dévisagent ou m'évitent, comme un original. Et moi, je fuis: ou bien je ferme les yeux pour dire «Non»; ou bien, malgré moi, je sens que mes yeux tout à coup vont m'échapper, tomber avec ces larmes ridicules que je ne peux plus contenir; ou bien je prends mes jambes à 
mon cou, je me mets à courir comme un fou et je suis sûr que cela les soulage. On n'a pas idée d'ailleurs de se promener comme ça, comme un sac à ça dans les rues. (Il me semble que, chaque fois, je peux lire cette phrase dans leurs pensées ou qu'ils sont prêts à éclater, à crier: Ça suffit! Ça est insupportable! Ça n'est pas pensable! Ça!)

Et voilà où j'en suis. Où «ça» en est, devrait-on dire... 